\title{
Analisis Pengaruh Variasi Arus dan Sudut Kampuh dengan Metode Pengelasan GTAW terhadap Sifat Mekanik dan Struktur Mikro Baja ST 41 Ridhwan Haliq ${ }^{1}$, Himawan Tri Raharjo ${ }^{2}$, \\ ${ }^{1}$ Mechanical Engineering, Institute Technology Kalimantan, Balikpapan. Email: ridhwanhaliq@itk.ac.id \\ ${ }^{2}$ Mechanical Engineering, Institute Technology Kalimantan, Balikpapan. Email: 03121013@itk.ac.id
}

\begin{abstract}
The objective of research is to determine the effect of welding current on the hardness, tensile strength, and microstructure from GTAW welding with ER70S2. This research used ST 41 low alloy steel material containing C $=0,16 \%, S i=0,23 \%, M n=0,69 \%, S=0,031 \%, P=0,019 \%$, yield point $40 \mathrm{~kg} / \mathrm{mm}^{2}$, tensile strength $52 \mathrm{~kg} / \mathrm{mm}^{2}$, dan elongation $32 \%$. ST 41 steel welding is carried out with current variations of $90 \mathrm{~A}, 110 \mathrm{~A}$ and $130 \mathrm{~A}$ with GTAW welding methode. Types of variation of the notch use are ][, $V$ and $X$. The specimens was subjected to hardness, tensile strength, and metallography. Based on the result of hardness test with the factor elimination method in obtaining the angle][ notch with current $90 \mathrm{~A}$, V notch with current $90 \mathrm{~A}$, and X notch with current 110 A. Tensile test results of the three materials, the highest tensile strength at the X notch with current $110 \mathrm{~A}$ is 416,8 $\mathrm{N} / \mathrm{mm}^{2}$. The lowest tensile strength is obtained at welds with] [ notch is $360.73 \mathrm{~N} / \mathrm{mm}^{2}$. From result of metallograph that we get if Xnotch with current $110 \mathrm{~A}$ is more stable, than ][ notch with current $90 \mathrm{~A}$ and $V$ notch with current $90 \mathrm{~A}$.
\end{abstract}

Keywords: GTAW (Gas Tungsten Arc Welding), low alloy steel, hardness, tensile

\begin{abstract}
Abstrak
Penelitian ini bertujuan untuk mengetahui pengaruh arus pengelasan terhadap kekerasan, kekuatan tarik dan struktur mikro pada pengelasan GTAW dengan filler ER70S2. Material yang digunakan dalam penelitian menggunakan bahan baja ST 41 paduan karbon rendah yang mengandung kadar $\mathrm{C}=0,16 \%, \mathrm{Si}=0,23 \%, \mathrm{Mn}=$ $0,69 \%, \mathrm{~S}=0,031 \%, \mathrm{P}=0,019 \%$, yield point $40 \mathrm{~kg} / \mathrm{mm}^{2}$, tensile strength $52 \mathrm{~kg} / \mathrm{mm}^{2}$, dan elongation $32 \%$. Pengelasan baja ST 41 dilakukan dengan variasi arus 90 A, 110 A dan 130 A dengan menggunakan pengelasan GTAW. Jenis variasi sudut kampuh yang digunakan adalah kampuh ][, V dan X. Kemudian spesimen dilakukan pengujian kekerasan, kekuatan tarik dan metalografi. Berdasarkan hasil pengujian kekerasan dengan metode eliminasi faktor didapatkan sudut kampuh ][ dengan arus 90A, sudut kampuh V dengan arus 90A, dan sudut kampuh X dengan arus 110A. Ketiga material tersebut dilakukan pengujian tarik dan didapatkan kekuatan tarik sambungan tertinggi pada sudut kampuh X sebesar 416,8 N/mm². Kekuatan tarik sambungan terendah didapatkan pada pengelasan menggunakan kampuh ][ sebesar 360,73 N/mm². Berdasarkan pengujian metalografi didapatkan grain size dari sudut kampuh $\mathrm{X}$ dengan arus 110A lebih stabil dibandingkan sudut kampuh ][ arus 90A dan sudut kampuh $\mathrm{V}$ arus $90 \mathrm{~A}$.
\end{abstract}

Kata Kunci: GTAW (Gas Tungsten Arc Welding), paduan karbon rendah, kekerasan, kekuatan tarik

\section{Pendahuluan}

Pengelasan adalah salah satu proses penggabungan logam dimana logam menjadi satu akibat panas las dengan atau tanpa pengaruh tekanan dan dengan atau tanpa logam pengisi. Pada pengelasan terjadi banyak perbahan sifat fisik dan mekanik, terutama pengelasan pada baja karbon rendah. Salah satu baja karbon rendah adalah baja ST 41. Baja ST 41 sering digunakan oleh industri-industri besar sebagai bahan dasar pembuatan komponen mesin maupun bahan konstruksi (Heru Suryanto. 2016). Salah satu jenis las yang sering digunakan umtuk proses penyambungan baja karbon rendah adalah GTAW ( Gas Tungsten Arc Welding), GTAW sering juga disebut TIG (Tungsten Inert Gas). Istilah GTAW berasal dari amerika sedangkan TIG berasal dari eropa. Pengelasan GTAW adalah jenis pengelasan yang menggunakan panas dari nyala pijar yang terbentuk antara filler tungsten yang tidak terumpan dengan menggunakan gas mulia sebagai pelindung terhadap pengaruh luar pada saat proses pengelasan. Filler las menggunakan batang wolfram yang dapat menghasilkan busur listrik tanpa ikut mencair. Pada penggunaan GTAW, kecepatan pengumpanan logam pengisi dapat diatur terlepas dari besarnya arus 
listrik sehingga terjadi penetrasi ke dalam logam induk. Cara pengaturan ini memungkinkan GTAW cocok digunakan pada pelat baja tipis maupun pelat baja tebal (Eko, 2017).

Besar kecilnya arus listrik pengelasan adalah contoh dari parameter pengelasan yang dapat mempengaruhi hasil pengelasan GTAW pada baja karbon rendah. Makin tinggi arus listrik pengelasan yang digunakan dalam pengelasan, makin tinggi pula penetrasi serta kecepatan pencairan. Arus listrik yang besar juga memperkecil percikan butiran, dan meningkatkan penguatan manik dan semakin tingginya arus listrik maka akan memperbesar daerah HAZ (Wiryosumarto, 1996). Untuk mengetahui pengaruh variasi kuat arus pada pengujian kekerasan daerah Las, HAZ dan Struktur Mikro pengelasan GTAW (Gas Tungsten Arc Welding) pada material ST 41 yang menghasilkan sifat mekanik yang paling baik, perlu dilakukan penelitian dan pengujian. Salah satu sifat mekanik yang paling penting dalam pengelasan adalah sifat kekerasan. Oleh karena itu, dalam tugas akhir ini akan dibahas mengenai pengelasan GTAW (Gas Tungsten Arc Welding) dengan variasi arus 90 A, 110 A,dan 130 A terhadap baja karbon rendah ST 41 serta pengaruhnya terhadap struktur mikro dan sifat mekanik (Inggil Khatulistiwa, 2014).

\section{Metode Penelitian}

Penelitian ini secara umum bertujuan untuk mengetahui pengaruh variasi arus las $90 \mathrm{~A}, 110 \mathrm{~A}$ dan 130 A. Alat yang dipergunakan adalah Mesin Las GTAW dengan olaritas DCEN dan tungsten (EWTh-2) sebagai filler. Bahan penelitian ini dengan menggunakan baja karbon rendah ST41 yang memiliki kandungan karbon kurang dari 0,3\% dengan ukuran $80 \mathrm{mmx} 10$ mmuntuk dijadikan sampel uji kekerasan dan pengambilan gambar struktur mikro. Untuk spesimen uji tarik kami membuat baja ST41 menjadi $200 \mathrm{~mm}$ x $20 \mathrm{~mm}$. komposisi dari material ST41 ini adalah $0.7 \% \mathrm{C}, 0.12 \% \mathrm{Si}, 0.61 \% \mathrm{Mn}, 1.5$ $\% \mathrm{P}, 2.4 \% \mathrm{~S}$.

\subsection{Rancangan Penelitian}

Penelitian ini menggunakan variasi arus pada pengelasan GTAW terhadap sifat mekanik dan struktur mikro baja ST41 dengan menggunakan Mesin las GTAW.

\subsection{Persiapan Spesimen Uji}

Persiapan spesimen uji merupakan langkah awal dari penelitian ini. Ada dua tahap dalam melakukan persiapan spesimen uji yakni pemilihan material yang akan digunakan dalam pemilihan filler dan arus las.

a. Pemilihan Material Spesimen Uji

Material yang digunakan pada penelitian ini adalah baja karbon rendah St 41 dengan ketebalan $9 \mathrm{~mm}$. Untuk spesimen uji kekerasan dan struktur mikro berukuran $80 \mathrm{~mm} \times 10 \mathrm{~mm}$ dan untuk spesimen uji tarik berukuran $200 \mathrm{~mm}$ x $20 \mathrm{~mm}$.

b. Pemilihan Filler Las, Arus Pengelasan

Filler yang digunakan pada penelitian ini adalah filler jenis tungsten (EWTh-2) dengan diameter 2,4 mm. Sedangkan untuk jenis dan besar arus yang digunakan pada penelitian ini adalah tipe arus searah DCEN (Direct Current Elektrode Negative) dengan besar arus bervariasi yaitu 90 A, 110 A dan 130 A.

\subsection{Pengujian Hasil Las}

Pengujian yang dilakukan adalah uji kekerasan, uji kekuatan tarik, dan uji foto mikro. Uji kekerasan dilakukan dengan tujuan untuk mengetahui nilai kekerasan dari spesimen uji, uji kekuatan tarik untuk mengetahui sifat mekanik dari sambungan las dan uji strukturmikro dilakukan bertujuan untuk melihat struktur mikro atau perubahan struktur mikro yang terjadi pada daerah las HAZ.

\subsection{Prosedur Penelitian}

Pengujian yang dilakukan adalah pengujian kekerasan, pengujian tarik dan pengujian struktur mikro. Pengujian yang pertama kali dilakukan adalah pengujian kekerasan. Pengujian nilai kekerasan tiap daerah (base metal, HAZ dan weld metal) dilakukan pengulangan pengambilan indentasi sebanyak tiga kali. Pengujian kedua menggunakan pengujian tarik untuk masing-masing sudut kampuh spesimen dan 
arus pengelasan yang digunakan berdasarkan hasil kekerasan yang terbaik yang didapatkan menggunakan metode eliminasi. Metode eliminasi merupakan metode pengurangan biasa dengan mengurangkan hasil kekerasan daerah satu dengan daerah lainnya. Setelah didapatkan selisihnya kemudian selisihnya ditotal, nilai total yang mendekati nol berarti memiliki nilai kekerasan antar daerah lebih seragam selanjutnya untuk masing-masing sudut kampuh dengan metode eliminasi dapat ditentukan material yang terbaik untuk dilakukan pengujian tarik. Setelah dilakukan pengujian tarik dilakukan pengujian struktur mikro terhadap semua spesimen.

\subsection{Pengujian Kekerasan}

Pengujian kekerasan ini dilakukan untuk mengetahui distribusi kekerasan di daerah base metal, Heat Affected Zone (HAZ) dan weld metal. Pengujian ini dilakukan dengan menggunakan alat uji kekerasan di Laboratorium Teknik Material dan Metalurgi ITK. Standar pengujian kekerasan yang digunakan adalah dengan metode rockwell B. Prosedur pengujian uji kekerasan mempersiapkan spesimen sesuai dengan standar, mempersiapkan peralatan pengujian hardness, untuk pengujian yang akan dilakukan 3 titik pengujian pada base metal, 3 titik pada HAZ dan 3 titik pada weld metal, pengujian dilakukan pada posisi atas, tengah dan bawah, meletakkan material uji pada meja kerja, menekan indentor pada masingmasing lokasi yang diinginkan pada masing-masing spesimen dengan beban yag ditentukan sesuai standar dan mencatat hasil pengukuran.

\subsection{Pengujian Struktur Mikro}

Setelah pembuatan spesimen uji struktur mikro selesai dilakukan seperti yang telah dijelaskan pada pembuatan spesimen uji struktur mikro, selanjutnya dilakukan pengambilan foto spesimen menggunakan mikroskop optik dengan pembesaran sesuai yang diinginkan. Hal tersebut dilakukan pada semua spesimen yang akan diuji hingga selesai.

\section{Hasil dan Pembahasan}

Pada penelitian mengenai analisis pengaruh variasi arus dan sudut kampuh terhadap hasil pengelasan baja ST 41 dengan metode GTAW ini, guna memperoleh data maka dilakukan beberapa pengujian berupa pengujian nilai kekerasan dan pengujian kekuatan tarik. Data-data yang diperoleh pada pengujian yang dilakukan nantinya akan digunakan sebagai analisa hasil pengelasan dengan metode gas tungsten arc welding (GTAW). Pada penelitian mengenai pengaruh arus pengelasan terhadap baja ST 41, untuk memperoleh data dilakukan beberapa pengujian berupa kekerasan dan kekuatan tarik.

\subsection{Hasil Uji Kekerasan}

Pada proses pengujian kekerasan dilakukan di lima daerah yaitu Base (1), HAZ (1), Weld Metal, HAZ (2) dan Base Metal (2) dengan pengambilan masing-masing daerah sebanyak tiga titik indentasi. Pengambilan data pada uji kekerasan menggunakan rockwell B

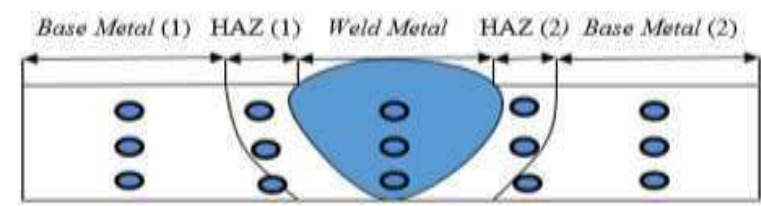

Gambar 1: Posisi titik pengujian kekerasan

\subsection{Hasil Uji Kekerasan Dengan sudut Kampuh II}

Tabel 1: Hasil uji kekerasan kampuh ][ dengan arus 90 A, 110A dan 130A

$\begin{array}{ccc}\text { Arus } & \text { Zona } & \text { Kekerasan (HRB) } \\ & \text { Base Metal } & 70,83 \\ 90 \mathrm{~A} & \text { HAZ } & 73,16 \\ & \text { Weld Metal } & 75,5\end{array}$




$\begin{array}{ccc}\text { Arus } & \text { Zona } & \text { Kekerasan (HRB) } \\ & \text { HAZ } & 75,3 \\ & \text { Base Metal } & 72,16 \\ \text { Arus } & \text { Zona } & \text { Kekerasan (HRB) } \\ & \text { Base Metal } & 70,66 \\ & \text { HAZ } & 75,83 \\ 110 \text { A } & \text { Weld Metal } & 77,5 \\ & \text { HAZ } & 76 \\ \text { Arus } & \text { Base Metal } & 72,66 \\ & \text { Zona } & \text { Kekerasan (HRB) } \\ & \text { Base Metal } & 71,6 \\ \text { 130 A } & \text { HAZ } & 76,16 \\ & \text { Weld Metal } & 80,66 \\ & \text { HAZ } & 77,16\end{array}$

Dari tabel 1 didapatkan nilai kekerasan didaerah Weld Metal untuk variasi arus 90 A dengan nilai ratarata 75,5 HRB. Untuk variasi arus 110 A dengan nilai rata-rata 77,5 HRB. Nilai rata-rata kekerasan dengan variasi arus $130 \mathrm{~A}$ adalah 80,66 HRB. Variasi arus $130 \mathrm{~A}$ memiliki nilai kekerasan lebih tinggi dari pada variasi arus $90 \mathrm{~A}$ dan $110 \mathrm{~A}$. perbedaan kekerasan pada variasi 130A lebih besar dibandingkan variasi 90A dan 110A, khususnya di daerah Weld metal dan HAZ. Berdasarkan tabel 1 dapat dibuat grafik uji kekerasan dengan masing-masing variasi arus untuk sudut kampuh ( ][ ) sebagai berikut.

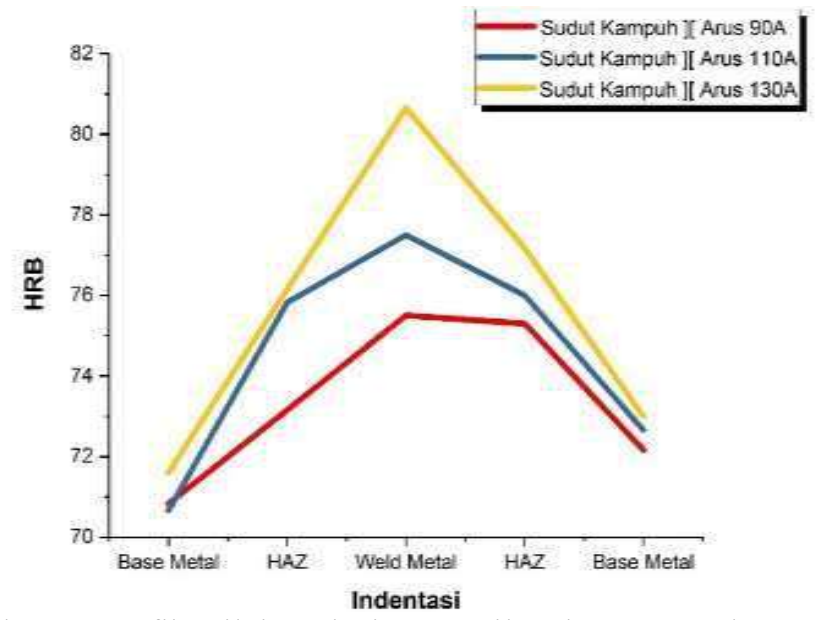

Gambar 2: Grafik Nilai Variasi Arus Uji Kekerasan Sudut Kampuh ][

Berdasarkan Gambar 2 Nilai kekerasan tertinggi pada sudut kampuh ][ terletak di daerah weld metal yaitu dengan nilai rata-ratanya 80,66 HRB dengan arus $130 \mathrm{~A}$.

\subsection{Hasil Uji Kekerasan Dengan sudut Kampuh V}

Dari tabel 2 didapatkan nilai kekerasan didaerah Weld Metal untuk variasi arus 90 A dengan nilai ratarata $77 \mathrm{HRB}$. Untuk variasi arus 110 A dengan nilai rata-rata 84,6 HRB. Nilai rata-rata kekerasan dengan variasi arus $130 \mathrm{~A}$ adalah 83,83 HRB. Variasi arus $110 \mathrm{~A}$ memiliki nilai kekerasan lebih tinggi dari pada 
variasi arus 90 A dan $130 \mathrm{~A}$. Berdasarkan tabel 2 dapat dibuat grafik uji kekerasan dengan masingmasing variasi arus untuk sudut kampuh $\mathrm{V}$ sebagai berikut.

Tabel 2: Hasil uji kekerasan kampuh V dengan arus $90 \mathrm{~A}, 110 \mathrm{~A}$ dan 130A

$\begin{array}{ccc}\text { Arus } & \text { Zona } & \text { Kekerasan (HRB) } \\ & \text { base metal } & 68,5 \\ \text { 90 A } & \text { HAZ } & 70,83 \\ & \text { Weld Metal } & 77 \\ & \text { HAZ } & 70,16 \\ \text { Arus } & \text { base metal } & 68,6 \\ & \text { Zona } & \text { Kekerasan (HRB) } \\ & \text { base metal } & 68,83 \\ \text { 110 A } & \text { HAZ } & 78 \\ & \text { Weld Metal } & 84,6 \\ & \text { HAZ } & 77,83 \\ \text { Arus } & \text { base metal } & 72 \\ & \text { Zona } & \text { Kekerasan (HRB) } \\ & \text { base metal } & 69,66 \\ & \text { HAZ } & 79,33 \\ & \text { Weld Metal } & 83,83 \\ & \text { HAZ } & 78,66 \\ & \text { base metal } & 72,66\end{array}$

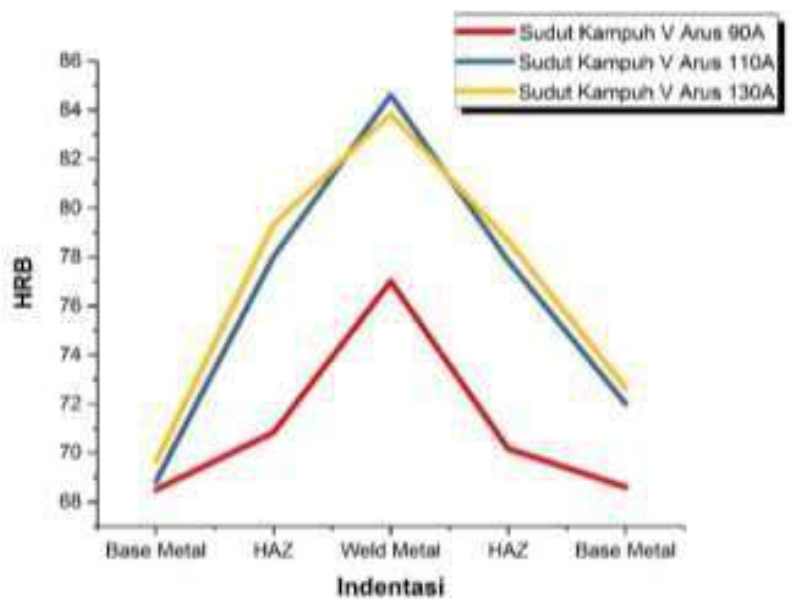

Gambar 3: Grafik Nilai Variasi Arus Uji Kekerasan Sudut Kampuh V

Berdasarkan Gambar 3 nilai kekerasan tertinggi pada sudut kampuh V terletak di daerah weld metal yaitu dengan nilai rata-ratanya 84,6 HRB dengan arus 110 A. Perubahan arus yang semakin besar akan memberikan dampak terhadap nilai kekerasan yang semakin meningkat pada material baja ST41. Penyetelan kuat arus pengelasan akan mempengaruhi hasil las. Bila menggunakan arus yang terlalu rendah akan menimbulkan penyalaan filler yang tidak stabil. Sebaliknya bila arus terlalu tinggi maka filler akan mencair terlalu cepat dan menghasilkan permukaan las yang lebih lebar. Pengambilan interval 
arus 90A, 110A dan 130A hanya sebagai pembanding. Dari grafik diatas arus 110A dan 130A adalah kondisi daerah kekerasan maksimum untuk operasi arus stabil. Operasi arus stabil adalah proses hasil pengelasan GTAW terhadap material ST41 untuk nyala api maksimum.pada arus 110A dan 130A hanya memiliki perbedaan nilai kekerasan di $\mathrm{HAZ} \geq 1 \mathrm{HRB}$. Sedangkan untuk arus $90 \mathrm{~A} \geq 8 \mathrm{HRB}$ memeiliki beda kekerasan yang sangat signifikan diantara kedua arus yang lain terhadap sudut kampuh V.

\subsection{Hasil Uji Kekerasan Dengan sudut Kampuh X}

Dari tabel 3 didapatkan nilai kekerasan didaerah Weld Metal untuk variasi arus 90 A dengan nilai ratarata 82,16 HRB. Untuk variasi arus 110 A dengan nilai rata-rata 79,83 HRB. Nilai rata-rata kekerasan dengan variasi arus $130 \mathrm{~A}$ adalah 76,5 HRB. Variasi arus $90 \mathrm{~A}$ memiliki nilai kekerasan lebih tinggi dari pada variasi arus $110 \mathrm{~A}$ dan $130 \mathrm{~A}$. Berdasarkan tabel 3 dapat dibuat grafik uji kekerasan dengan masing-masing variasi arus untuk sudut kampuh $\mathrm{X}$ sebagai berikut.

Tabel 3: Hasil Uji Kekerasan Kampuh X dengan Arus 90 A, 110A dan 130A

Arus

Zona

base metal

HAZ

$90 \mathrm{~A}$

Weld Metal

HAZ

base metal

Arus

Zona

base metal

HAZ

$110 \mathrm{~A}$

Arus

$130 \mathrm{~A}$

$130 \mathrm{~A}$

HAZ

base metal

Zona

base metal

HAZ
Kekerasan (HRB)

$$
71,5
$$

77,5

82,16

76

70,16

Kekerasan (HRB)

70,83

76,83

Weld Metal

79,83

76,5

70,66

Kekerasan (HRB)

71,5

71,83

Weld Metal

76,5

HAZ

74,33

base metal

72,16

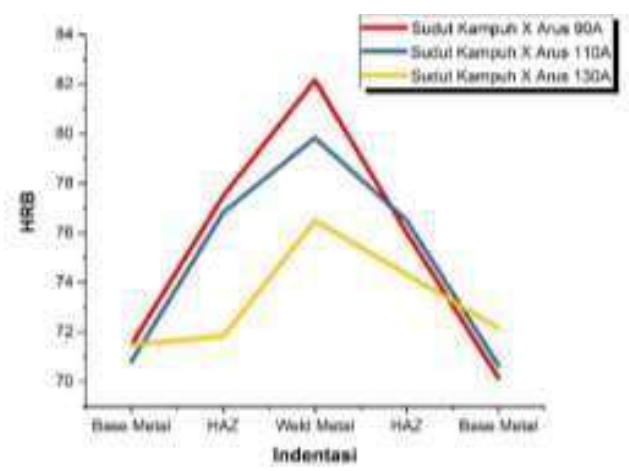

Gambar 4: Grafik Nilai Variasi Arus Uji Kekerasan Sudut Kampuh X 
Gambar 4 menunjukan bahwa nilai kekerasan tertinggi pada sudut kampuh X terletak di daerah weld metal yaitu dengan nilai rata-ratanya $82,16 \mathrm{HRB}$ dengan arus $110 \mathrm{~A}$. Hasil dari sudut kampuh $\mathrm{X}$ berbanding terbalik dengan sudut kampuh $\mathrm{V}$, dimana hasil kekerasan tertinggi dimiliki oleh arus $90 \mathrm{~A}$ yang nyala api fillernya cendrung tidak stabil. Perbedaan ini terjadi akibat bentuk sudut kampuh yang mengharuskan pengelasan di 2 sisi. Saat pengelesan dilakukan di kedua sisi maka hasil variasi arus terhadap kekerasan di daerah HAZ, weld metal dan base metal akan berbanding terbalik dari sudut kampuh $\mathrm{V}$ yang hanya dilakukan di satu sisi pengelasan.

\subsection{Pemilihan Material Uji Tarik berdasarkan hasil Uji Kekerasan pada Masing-masing Sudut Kampuh}

Spesimen pengujian terdiri dari pengujian tarik untuk kualitas kekuatan tarik baja paduan rendah hasil pengelasan GTAW dengan filler ER-70S2 dan kekuatan tarik daerah las baja paduan rendah. Data hasil pengujian kekerasan yang telah dilakukan dengan menggunakan metode Rockwell $B$, selanjutnya dilakukan metode eliminasi faktor untuk mendapatkan material yang tepat untuk pengujian tarik. Material yang tepat untuk dijadikan pengujian tarik adalah material yang memeiliki selisih nilai kekerasan mendekati nol. Hal ini dilakukan untuk menghindari adanya konsentasi tegangan.

Dari hasil perhitungan Uji kekerasan yang di dapat maka pemilihan untuk uji kekuatan tarik dengan sudut kampuh yang didapat dari masing-masing sudut kampuh maka didapat yang terbaik dari masingmasing variasi arus. Untuk menentukan material baja ST 41 yang terbaik dari pengujian kekerasan dilakukan eleminasi faktor antara indentasi satu dengan indentasi yang lainnya pada material yang sama, hal ini dilakukan untuk mendapatkan eliminasi faktor yang mendekati nilai Nol (0). Untuk setiap sudut kampuh dari tiga (3) variasi arus dipilih satu arus yang terbaik untuk dilakukan uji tarik.

Tabel 4: Hasil pengujian kekerasan variasi sudut kampuh untuk kualitas tarik

\begin{tabular}{|c|c|c|c|c|c|c|}
\hline \multirow{2}{*}{$\begin{array}{c}\text { Sudut Kampuh } \\
][\end{array}$} & \multirow{2}{*}{$\begin{array}{c}\text { Spesimen } \\
90 \mathrm{~A}\end{array}$} & \multicolumn{4}{|c|}{ Metode Eliminasi } & \multirow{2}{*}{$\begin{array}{c}\begin{array}{c}\text { Nilai Eliminasi } \\
\text { Faktor }\end{array} \\
1,33\end{array}$} \\
\hline & & 2,33 & 2,34 & $-0,2$ & $-3,14$ & \\
\hline & $110 \mathrm{~A}$ & 5,17 & 1,67 & $-1,5$ & $-3,34$ & 2 \\
\hline & $130 \mathrm{~A}$ & 4,56 & 4,5 & $-3,5$ & $-4,16$ & 1,4 \\
\hline \multirow[t]{3}{*}{ v } & $90 \mathrm{~A}$ & 2,23 & 6,17 & $-8,17$ & $-0,33$ & $-0,1$ \\
\hline & $110 \mathrm{~A}$ & 9,17 & 6,6 & $-6,77$ & $-5,83$ & 3,17 \\
\hline & $130 \mathrm{~A}$ & 9,67 & 4,5 & $-5,17$ & -6 & 3 \\
\hline \multirow[t]{3}{*}{$x$} & $90 \mathrm{~A}$ & 6 & 4,66 & $-6,16$ & $-5,84$ & $-1,34$ \\
\hline & $110 \mathrm{~A}$ & 6 & 3 & $-3,33$ & $-5,84$ & $-0,17$ \\
\hline & $130 \mathrm{~A}$ & 0,33 & 4,67 & $-2,17$ & $-2,17$ & 0,66 \\
\hline
\end{tabular}

Tabel 4 menunjukan nilai eliminasi faktor mendekati nilai nol (0). Dari variasi arus 90 A, 110 A dan 130 A dari sudut kampuh ][ didapat yang terbaik yang mendekati nilai nol (0) di arus 90 A dengan nilai yang didapat 1,33, dari variasi arus $90 \mathrm{~A}, 110 \mathrm{~A}$ dan $130 \mathrm{~A}$ untuk sudut kampuh $\mathrm{V}$ didapat yang terbaik diarus 90 A dengan nilai yang didapat $-0,1$ dan dari variasi arus $90 \mathrm{~A}, 110 \mathrm{~A}$ dan $130 \mathrm{~A}$ untuk sudut kampuh $\mathrm{X}$ didapat nilai yang terbaik di arus 110 A dengan nilai yang didapat $-0,17$. Eliminasi faktor ini untuk mendapatkan nilai rata-rata kekerasan dari bagian weld metal, HAZ, dan base metal. Semakin mendekati 0 maka titik konsentrasi tegangan semakin kecil pada material lasan.

\subsection{Hasil Pengujian Tarik dengan Sudut Kampuh I[, V dan X}

Berdasarkan Gambar 5 dapat terlihat material ST 41 yang dilas dengan sudut kampuh ( ][ ) yang berwarna merah lebih cepat putus daripada material dengan sudut kampuh (V) berwarna biru dan sudut kampuh ( $\mathrm{X}$ ) berwarna kuning. Hal ini menandakan material dengan sudut kampuh (X) lebih ulet dibandingkan material dengan sudut kampuh (V) dan sudut kampuh ( ][ ). Simbol bintang pada Gambar 5 menunjukkan break point. 


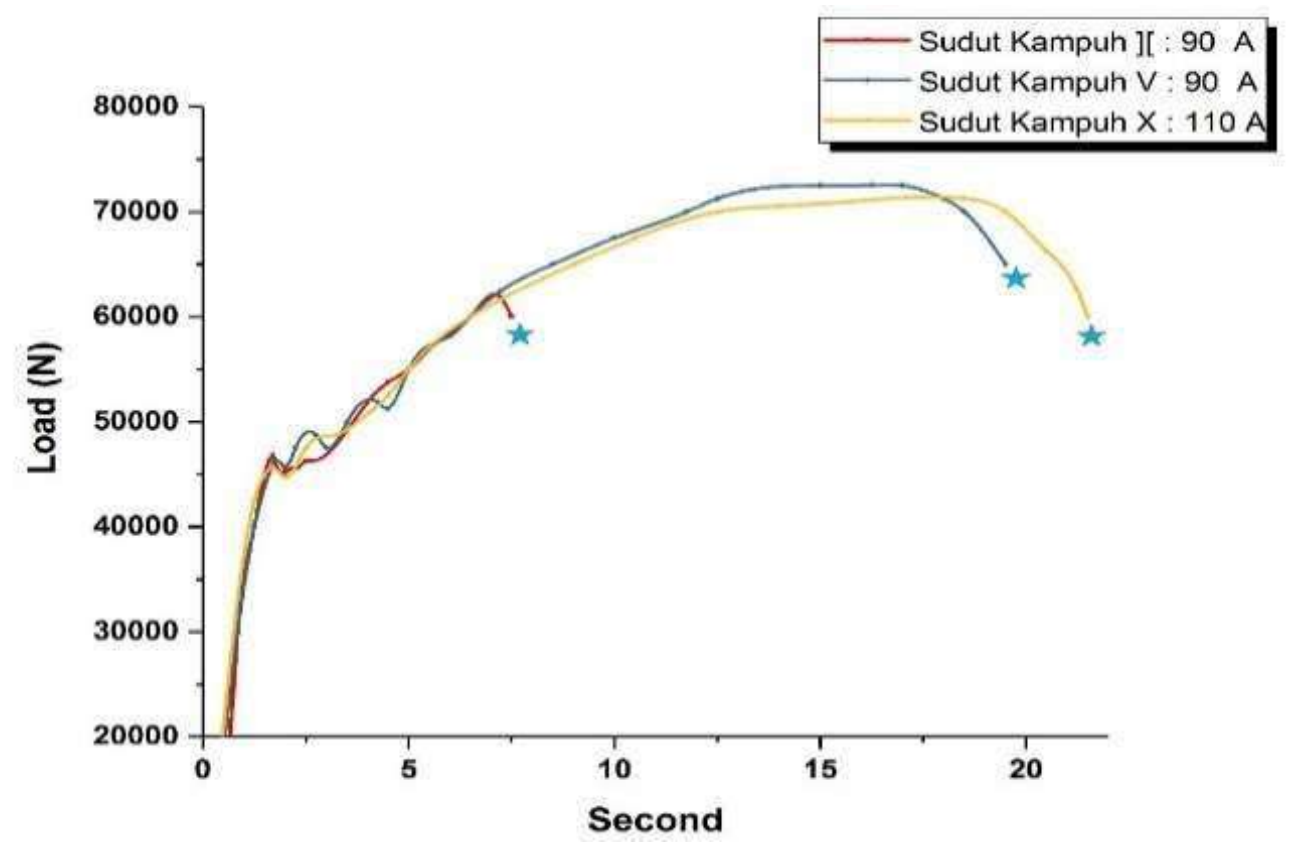

Gambar 5: Grafik Uji Tarik Spesimen Kampuh ][, V dan X

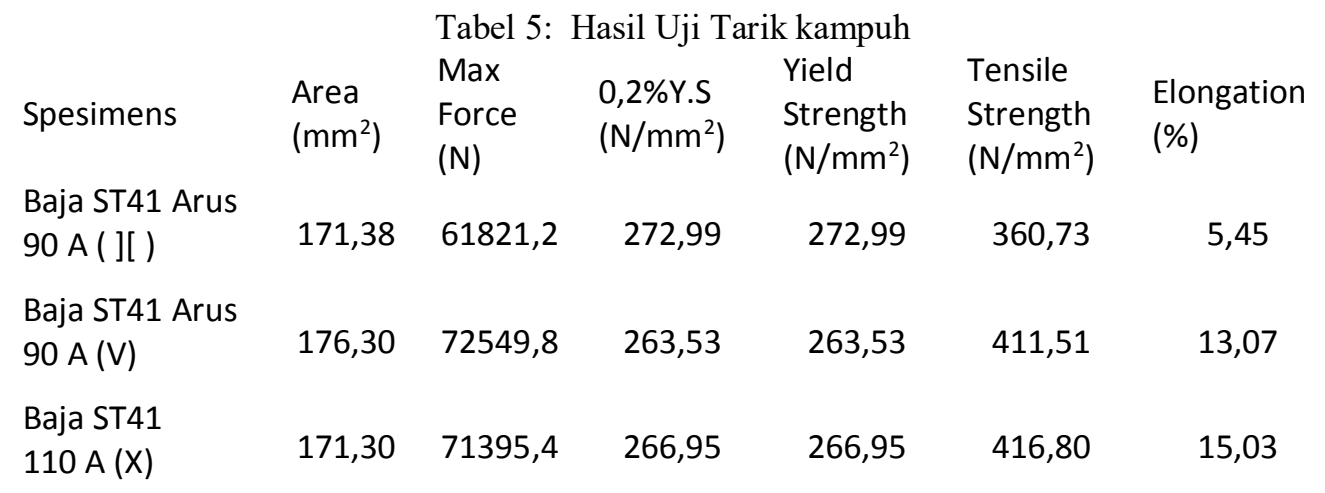

Berdasarkan Tabel 5 didapatkan hasil uji tarik, nilai kekuatan tarik terendah terdapat pada spesimen kampuh I dengan arus 90 A sebesar 360,73 N/mm² dan Untuk nilai kekuatan tarik kampuh V dan X cenderung sama. Nilai kekuatan tarik kampuh V arus 90 A sebesar 411,51 N/mm² dan kekuatan tarik tertinggi pada kampuh X arus 110 A sebesar 416,80 N/mm². Bila dibandingkan dengan dengan sertifikat inspeksi yang dimiliki baja ST41 dengan Grade JIS-G-3101 maka nilai tarik dari material tersebut setelah di las mengalami penurunan, hal ini disebabkan konsentrasi tegangan berpusat pada daerah HAZ yang memungkinkan terjadinya segragasi antara base metal dengan weld metal. 

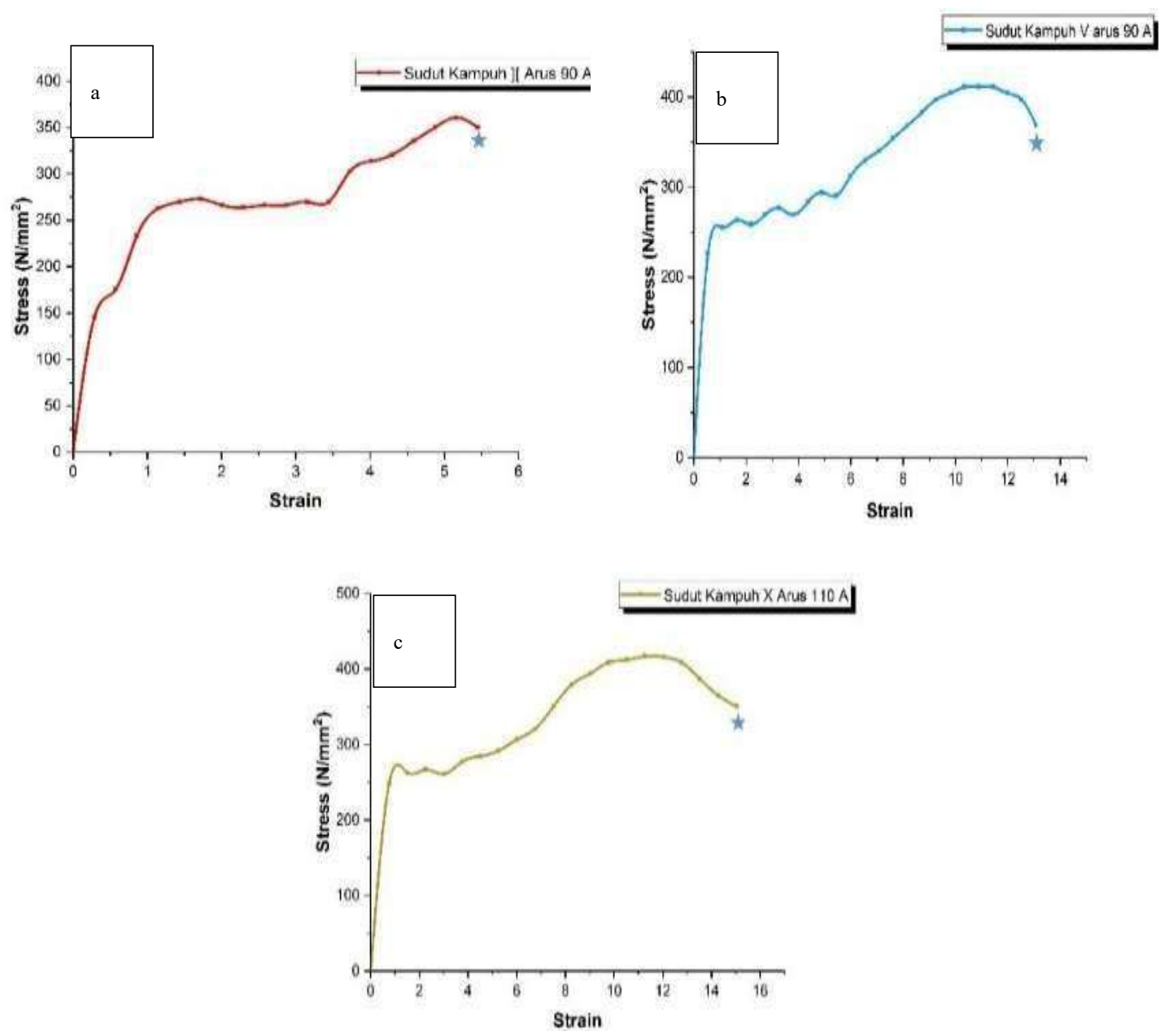

Gambar 6: Kurva Tegangan Regangan (a. Sudut kampuh ][ , b. Sudut kampuh V, c. Sudut kampuh X)

Gambar 6 adalah konversi dari grafik kurva load/second menjadi kurva tegangan/regangan yang besar regangan yang dihasilkan sudut kampuh ][ yang berwarna merah sebesar 5,45, untuk sudut kampuh $\mathrm{V}$ yang berwarna biru memiliki regangan sebesar 13,07 sedangkan untuk kampuh X memiliki regangan paling tinggi dibandingkan dengan yang lain dengan nilai regangan sebesar 15,03 dengan memiliki nilai regangan paling tinggi hal ini berarti material dengan sudut kampuh $\mathrm{X}$ memiliki keuletan yang paling tinggi dibandingkan sudut kampuh $\mathrm{V}$ dan sudut kampuh ][. Simbol bintang pada Gambar 4.6 menunjukkan break point.

\subsection{Hasil Uji Mikrostruktur}

Pengujian struktur mikro dilakukan untuk mengetahui perubahan struktur mikro yang terjadi akibat pengelasan. Pengambilan struktur mikro dilakukan pada daerah HAZ (Heat Affected Zone) dikarenakan daerah ini paling berpengaruh mengalami perubahan struktur mikro.

Gambar 7 menunjukan bahwa pengotor pada gambar C lebih banyak dibandingkan gambar A dan B untuk daerah HAZ fase delta ferrite, austenite, dan karbida masih sulit ditemukan pada gambar ini. Pengotor pada daerah HAZ akan menimbulkan tegangan sisa yang besar, hal ini akan berbanding lurus dengan hasil uji tarik yang diperoleh, untuk gambar A didapatkan tensile strength 360,73 N/mm, lebih rendah dibandingkan hasil yang lainnya. Semakin banyak pengotor (impurity) dari suatu material maka akan semakin rendah kekuatan tarik yang diperoleh. struktur mikro di daerah HAZ dengan sudut kampuh ][ dimana grain size pada gambar A terlihat ukuran grain size lebih besar dibandingkan struktur 
mikro gambar B dan $\mathrm{C}$ sedangkan pada gambar $\mathrm{C}$ ukuran grain size sangat kecil dibandingkan gambar A dan gambar B.
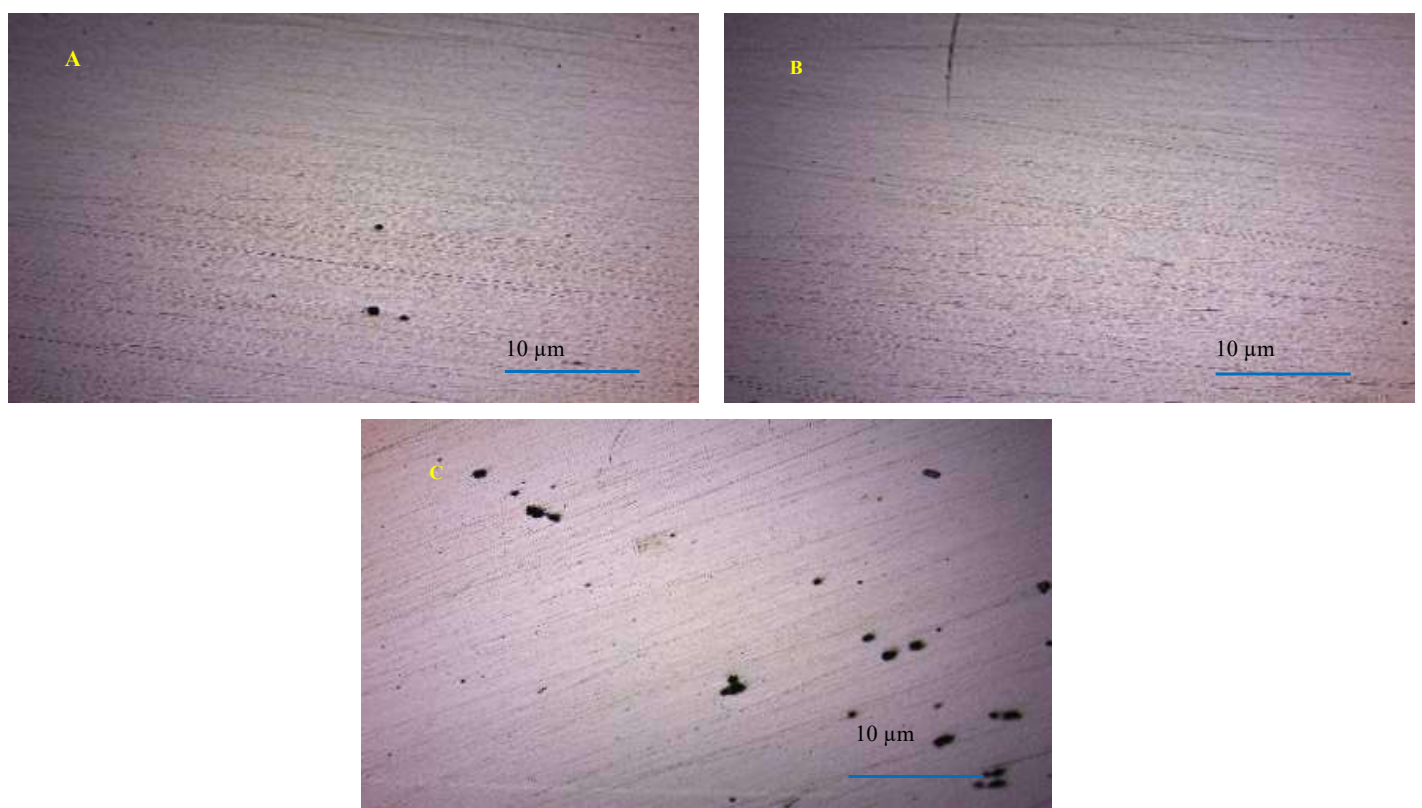

Gambar 7: Struktur Mikro dengan perbesaran 10x sudut kampuh ][ (a. 90 A, b. 110 A dan c. 130A)
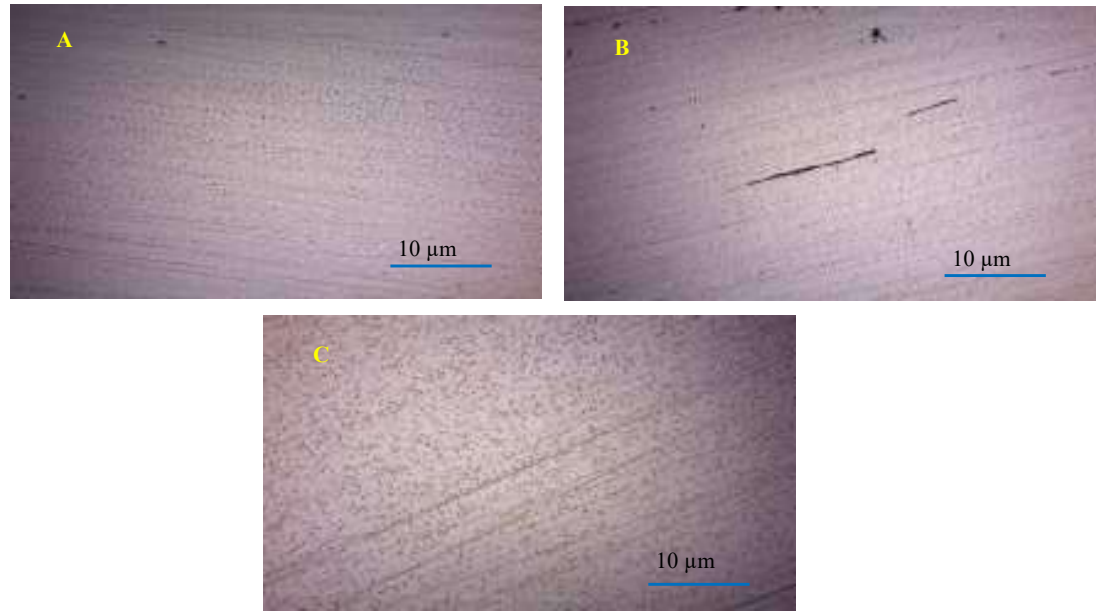

Gambar 8: Struktur Mikro dengan perbesaran 10x sudut kampuh V (a. 90 A, b. 110 A dan c. 130A)

Berdasarkan Gambar 8 menunjukkan foto struktur mikro di daerah HAZ dengan sudut kampuh V dimana grain size pada gambar A terlihat lebih besar dibandingkan struktur mikro gambar B, untuk gambar B terlihat grain size sangat kecil dan ukuran grain size pada gambar $\mathrm{C}$ terlihat berukuran paling besar. Pada sudut kampuh V yang terlihat pula adanya presipitasi bintik hitam yang tersebar secara merata didaerah batas butir yang masih kurang terlihat jelas. Presipitasi tersebut diduga adalah presipitasi karbida. Gambar C lebih jeals dibadningkan gambar yang lain. Gambar diatas merupakan daerah HAZ yang telah mengalami rangkaian siklus termal yakni pemanasan hingga mencapai temperatur tertentu yang kemudian dilanjutkan dengan pendinginan, sehingga daerah ini merupakan daerah yang paling kritis pada sambungan las. Panas dari pengelasan merubah ukuran butir pada daerah dekat logam las. 


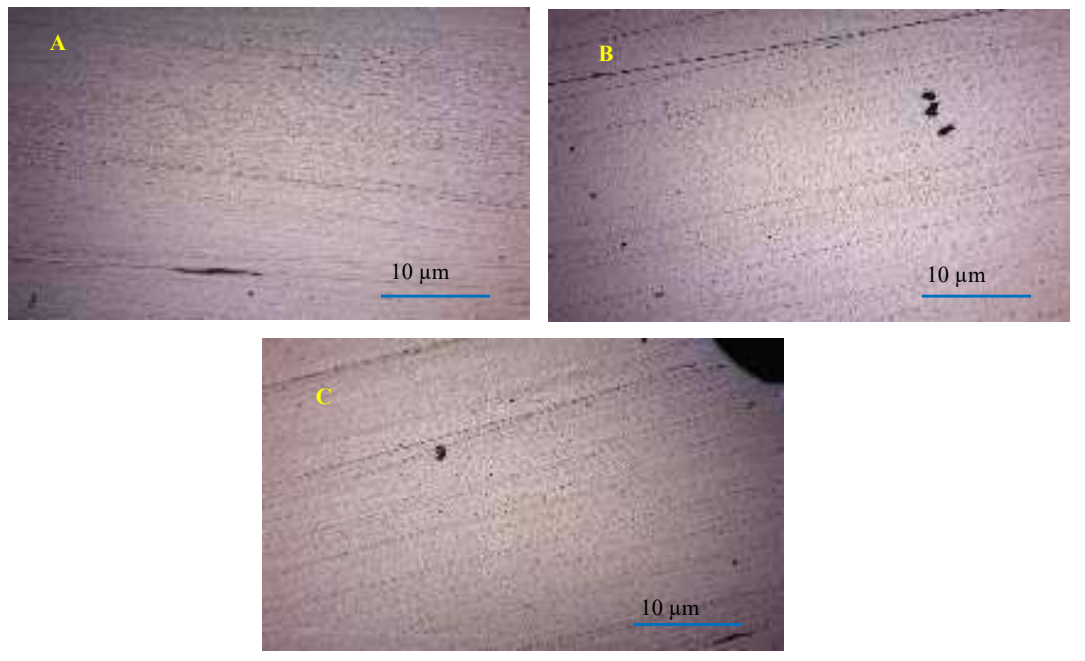

Gambar 9: Struktur Mikro dengan perbesaran 10x sudut kampuh X (a. 90 A, b. 110 A dan c. 130A)

Berdasarkan Gambar 9 menunjukkan foto struktur mikro di daerah HAZ dengan sudut kampuh X dimana grain size pada gambar B terlihat lebih besar dibandingkan struktur mikro gambar A dan C, untuk gambar $\mathrm{C}$ terlihat ukuran grain size sangat kecil. Pada batas lebur dengan logam las, struktur butir mengalami pertumbuhan yang berawal dari logam induk menuju pusat inti las. Seiring dengan meningkatnya temperatur pada logam las, pertumbuhan butir akan menuju pusat inti las dengan struktur mikro yang memiliki bentuk berbutir Panjang (columnar grains). Pada gambar 9 hampir sama seperti gambar 8 dan 7, hanya saja batas butir pada gmabr 9 dengan sudut kampuh $\mathrm{X}$ lebih terlihat dari pada gambar yang lain. Fase putih yang tidak memiliki corak di indikasikan sebagai daerah austenite. Diantara struktur mikro logam las dan struktur mikro HAZ terjadi perbedaan ukuran butiran, ukuran grain size pada lasan lebih banyak presipitasi karbida dibandingkan di daerah HAZ, presipitasi karbida adalah yang mengakibatkan kekerasan dari suatu logam akan meningkat. Hal ini berbanding lurus dengan hasil uji kekerasan dari Tabel 1, Table 2 dan Table 3. Weld metal pada GTAW memiliki kekerasan yang lebih tinggi dibandingkan base metalnya. Pada beberapa khasus, bila mengacu pada standar struktur mikro yang didapatkan, seharusnya dapat terlihat sedikit dendrit, akan tetapi gambar asih sulit untuk dianalisis.

\subsection{Analisis Hasil Uji Kekerasan dan Uji Tarik Terhadap Struktur Mikro}

Berdasarkan hasil penelitian yang telah dilakukan maka dapat dilakukan analisis hasil uji kekerasan dan uji tarik terhadap uji struktur mikro untuk ketiga spesimen yang telah diuji tarik yaitu spesimen sudut kampuh ][ arus $90 \mathrm{~A}$, sudut kampuh V arus $110 \mathrm{~A}$ dan sudut kampuh X arus $110 \mathrm{~A}$. Spesimen dengan sudut kampuh ][ arus 90 A memiliki nilai kekerasan pada daerah weld metal lebih keras di bandingkan base metal, untuk kekuatan tarik yang dihasilkan cenderung rendah yaitu sebesar $360,73 \mathrm{~N} / \mathrm{mm}^{2}$ dan terhadap struktur mikro yang dihasilkan memiliki ukuran grain size berukuran besar.

Spesimen dengan sudut kampuh $\mathrm{V}$ arus 90 A memiliki nilai kekerasan pada daerah weld metal lebih keras di bandingkan base metal, untuk kekuatan tarik yang dihasilkan cenderung tinggi yaitu sebesar $411,51 \mathrm{~N} / \mathrm{mm}^{2}$ dan terhadap struktur mikro yang dihasilkan memiliki ukuran grain size berukuran sedang. Spesimen dengan sudut kampuh $\mathrm{X}$ arus 110 A memiliki nilai kekerasan pada daerah weld metal lebih keras di bandingkan base metal, untuk kekuatan tarik yang dihasilkan cenderung tinggi yaitu sebesar $416,80 \mathrm{~N} / \mathrm{mm}^{2}$ dan terhadap struktur mikro yang dihasilkan memiliki ukuran grain size berukuran besar.

\section{Kesimpulan}

Berdasarkan beberapa pengujian yang telah dilakukan dapat disimpulkan bahwa : 
1. Pada proses pengelasan baja karbon rendah ST 41 ketebalan $9 \mathrm{~mm}$ dengan menggunakan proses pengelasan GTAW dan filler ER70S2 pada kuat arus pengelasan 90 A, 110 A, dan 130 A dihasilkan kualitas sambungan yang cukup baik. Dari pengujian kekerasan didapatkan hasil kekerasan terbaik dengan metode eliminasi dimana dicari nilai yang paling mendekati nilai nol untuk kampuh ][ yaitu arus $90 \mathrm{~A}$ sebesar 1,33, kampuh $\mathrm{V}$ yaitu pada arus $90 \mathrm{~A}$ sebesar $-0,1$, dan kampuh $\mathrm{X}$ yaitu pada arus 110 A sebesar $-0,17$.

2. Untuk pengujian tarik dengan variasi kampuh ][, kampuh $\mathrm{V}$, dan kampuh $\mathrm{X}$ dimana arus yang dipakai berdasarkan hasil uji kekerasan terbaik untuk kampuh ][ arus digunakan arus $90 \mathrm{~A}$, kampuh $\mathrm{V}$ digunakan arus $90 \mathrm{~A}$, dan untuk kampuh $\mathrm{X}$ digunakan arus $110 \mathrm{~A}$. Kekuatan tarik tertinggi sebesar $416,80 \mathrm{~N} / \mathrm{mm}^{2}$ dengan menggunakan kampuh $\mathrm{X}$ arus $110 \mathrm{~A}$ dan kekuatan tarik terendah sebesar $360,73 \mathrm{~N} / \mathrm{mm}^{2}$ dengan menggunakan arus $90 \mathrm{~A}$. Untuk pengujian struktur mikro terdapat perubahan ukuran grain size didaerah HAZ, untuk kampuh X ukuran grain size sedang dan homogen terdapat pada arus 110 A sedangkan untuk sudut kampuh ][ dan V ukuran grain size homogen terdapat pada arus $90 \mathrm{~A}$.

3. Untuk menentukan metode pengelasan yang tepat guna didapatkan berdasarkan hasil uji kekerasan untuk mendapatkan arus yang terbaik untuk nantinya dipakai uji tarik. Untuk sudut kampuh ][ arus yang terbaik yaitu arus $90 \mathrm{~A}$, kampuh $\mathrm{V}$ arus yang terbaik yaitu arus $90 \mathrm{~A}$, dan kampuh $\mathrm{X}$ arus yang terbaik arus $110 \mathrm{~A}$. Setelah dilakukan uji tarik untuk mendapatkan material dengan keuletan tertinggi yaitu dengan menggunakan metode pengelasan kampuh $\mathrm{X}$ dan arus $110 \mathrm{~A}$.

\section{Daftar Pustaka}

Aljufri. (2008). Pengaruh Variasi Sudut Kampuh V Tunggal Dan Kuat Arus Pada Sambungan Logam Aluminium - Mg 5083 Terhadap Kekuatan Tarik Hasil Pengelasan Tig.Universitas Sumatera Utara. Medan.

ASTM E407, 2007. Standard Practice for Microetching Metals and Alloy, USA.

Becker., R. J. \& George F. Vander Voort (2004). ASM Handbook Metallography and Microstructures. ASM International, Volume 9, ISBN: 978-0-87170-706-2.

Sunaryo, H. (2008). Teknik Pengelasan Kapal Jilid I Untuk SMK. Direktorat Pembinaan Sekolah Menengah Kejuruan, Departemen Pendidikan Nasional. Jakarta.

Cary, H. B. (1993). Modern Welding Technology, A Simon \& Schuster Company, Englewood Cliffs, New Jersey.

Wiryosumarto, H Dan Okumura, T. (2000). Teknologi Pengelsan Logam. Cetakan Ke 8. Pradnya Paramita. Jakarta.

Katulistiwa, Inggil. (2014). Pengaruh besar arus pengelasan dan jenis filler las Tungsten Inert Gas (TIG) pada baja karbon rendah terhadap kekuatan tarik dan bending. Surabaya: Universitas Negeri Surabaya. 